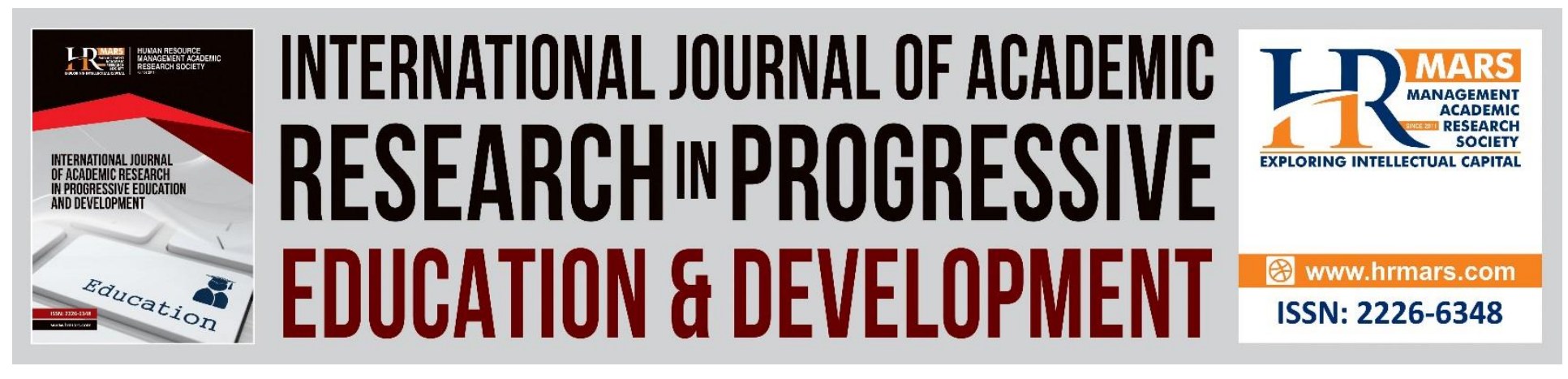

\title{
Factors Influencing Career Choice Among Final Semester Undergraduate Students of a Business Management Faculty in A Malaysian Public University
}

Muhamad Khalil Omar, Maliza Delima Kamarul Zaman and Muhammad Hafiz Aziz

To Link this Article: http://dx.doi.org/10.6007/IJARPED/v10-i2/9830

DOI:10.6007/IJARPED/v10-i2/9830

Received: 20 February 2021, Revised: 23 March 2021, Accepted: 02 April 2021

Published Online: 25 April 2021

In-Text Citation: (Omar et al., 2021)

To Cite this Article: Omar, M. K., Zaman, M. D. K., \& Aziz, M. H. (2021). Factors Influencing Career Choice Among Final Semester Undergraduate Students of a Business Management Faculty in A Malaysian Public University. International Journal of Academic Research in Business and Social Sciences, 10(2), 361-373.

Copyright: (C) 2021 The Author(s)

Published by Human Resource Management Academic Research Society (www.hrmars.com)

This article is published under the Creative Commons Attribution (CC BY 4.0) license. Anyone may reproduce, distribute, translate and create derivative works of this article (for both commercial and non-commercial purposes), subject to full attribution to the original publication and authors. The full terms of this license may be seen

at: http://creativecommons.org/licences/by/4.0/legalcode

Vol. 10(2) 2021, Pg. 361 - 373

http://hrmars.com/index.php/pages/detail/IJARPED

JOURNAL HOMEPAGE

Full Terms \& Conditions of access and use can be found at http://hrmars.com/index.php/pages/detail/publication-ethics 


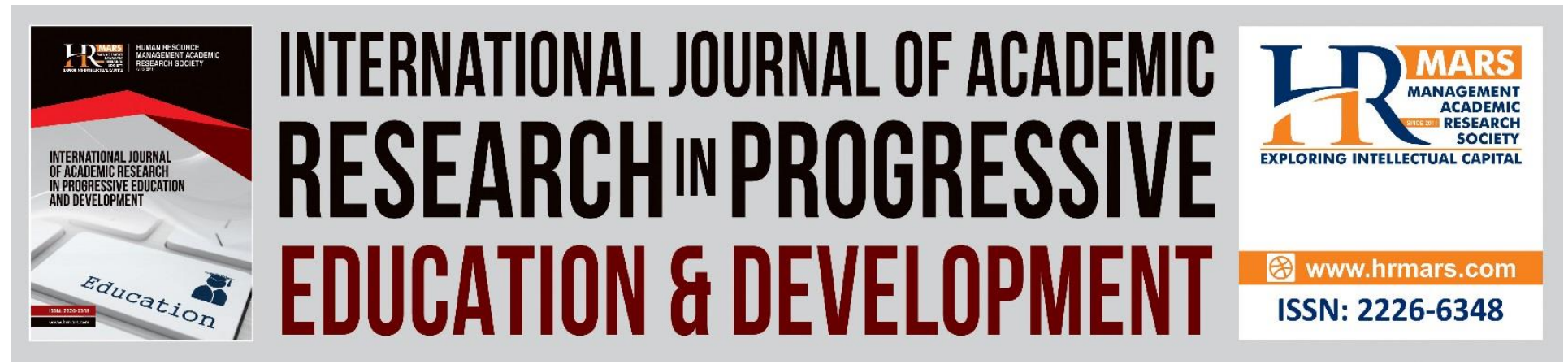

\title{
Factors Influencing Career Choice Among Final Semester Undergraduate Students of a Business Management Faculty in A Malaysian Public University
}

\author{
Muhamad Khalil Omara, Maliza Delima Kamarul Zaman ${ }^{\mathrm{b}}$ and \\ Muhammad Hafiz Aziz ${ }^{\mathrm{C}}$ \\ ${ }^{a, b}$ Faculty of Business and Management, Universiti Teknologi MARA, Cawangan Selangor, \\ Kampus Puncak Alam,42300 Bandar Puncak Alam, Selangor, Malaysia, 'Faculty of Business and \\ Management, Universiti Teknologi MARA, 40450 Shah Alam, Selangor, Malaysia \\ Email: akhalil.omar@uitm.edu.my,bmalizadelima@uitm.edu.my, \\ cmuhammadhafizaziz1810@gmail.com
}

\begin{abstract}
The topic of undergraduates and recent graduates' career choice has sparked the interest of many people these years. This paper aims to study the factors that influence students' career choices. Among the variables included in this study are personality, parents or guardians, peer groups, career guidance counsellors, environment, opportunity, and economic considerations. The targeted population was 436 final semesters of undergraduate students at the Faculty of Business and Management, UiTM Puncak Alam. Email questionnaires were distributed to all the respondents using a census to ensure a good response rate. A minimum sample of 205 was identified. This study used a multiple regression analysis to identify the relationship between personality, parents or guardians, peer groups, career guidance counsellors, environment, opportunity, economic considerations, and career choice. Findings revealed that only five (5) variables significantly influence students: personality, parents or guardians, peer groups, career guidance counsellors, and environment while economic consideration factors were not significant. However. Peer groups showed a negative relationship with students' career choices. Besides, the result of independent samples t-test revealed a significant difference between the mean group of residencies during the study regarding career guidance counsellors and opportunity. Thus, it is recommended that every party involved need to play a significant role in making a precise career choice so that they may not feel dissatisfied when they pursue a career, especially when the career is not up to what they really want.
\end{abstract}


Vol. 10, No. 2, 2021, E-ISSN: $2226-6348$ @ 2021 HRMARS

Keywords: Career Choice, Undergraduate, Students, Personality, Career Guidance Counsellors, Environment, Economic Considerations

\section{Introduction}

Study years are vital for adolescents since they are in an impermanent period from study years to work. The topic of undergraduates and recent graduates' career choices have sparked the interest of many people in these years (Wong, Lim, Lim, \& Hong, 2019). Ng, Gossett, Chinyoka, and Obasi (2016) also agreed that a wrong career choice can result in unemployment. Students who are about to finish their education and enter the labour market will increase competition among the unemployed. Failure to make the right career choices will affect their success in obtaining a career and contributing to the unemployment problem ( $\mathrm{Ng}$ et al., 2016). Looking at the situation at Universiti Teknologi MARA (UiTM), there are many students currently studying at this university with a total of 160,957 students (University Transformation Division, 2019). It can be estimated that UiTM graduates will face a tremendous competition pursuing a career. A survey found out that most unemployed graduates are from the social sciences, business, and law fields with a total of 35 percent (Leo, 2019). It further states that as the number of graduates carries on increasing each year, students are fronting fierce competition amid a shaky economic condition and being a university graduate sadly no longer promises you a career nowadays. This situation if left unsolved will lead to many disadvantages especially for the students who will enter the competition in the labour market in the future. Without proper guidance on career choice, students may be unable to make a career choice or make improper career choices which at the end lead to unemployment problems which have already been a talk of the town. Hence, it is essential to study the career choice among undergraduate students in business major in UiTM to reduce the unemployment rate of future business graduates.

Gwelo (2019) mentioned that personality type is among the crucial factors to be observed thoroughly when choosing a career. The inability to match personality type with a career refers to everlasting mistakes and cause for disappointment during the learning process and future tension for after graduation. Gwelo (2019) also stated that parents have established to be a source of advice on their child's career development. A lot of studies have been highlighted in Bandura's Social Cognitive Theory where individuals learn by observing (Mtemeri, 2017). Students tend to make their parents a model for things related to the outside world by observing and learning from them. Research by Koech et al. (2016) stated that factors that predict the decision on choosing the proper career are the fascinating point to university students. However, Gwelo (2019) stated that some research was concentrated and was limited to secondary schools, ignoring the university level (Eremie \& Ibifari, 2018; Raheem et al., 2018). On top of that, Wong et al., (2019) mentioned that there is a lack of studies on the career choice of undergraduate students in Malaysian as well as a lack of studies that prioritize career choice. This study is motivated by the lack of proven data that discussed on undergraduates' career choices in Malaysia and based on a comprehensive perception of the influence of personality, parents or guardians, peer groups, career guidance counsellors, environment, opportunity, and economic considerations on students' career choices that are supported by the previous literature. The purpose is to understand factors influencing undergraduate students' career choices at the 
Faculty Business and Management, UiTM Puncak Alam and to come out with recommendations on how to aid them in making a proper career choice while reducing the unemployment problem among business graduates in the future.

\section{Literature Review}

\section{Career Choice}

Career is described as an individual trajectory in their career, workplace, and position in a career from beginning to end. It is associated with the individual's continuous development in a career as they are engaged in a particular working sector and gain important skills and experience to attain career growth (Ates, 2016). Career choice is an important problem in the evolving lives of teenagers since it is described to be connected with optimistic as well as detrimental physical, psychological, and socioeconomic disparities that persevere well ahead of the youthful age into an individual's adult life (Bubic' \& Ivaniševic, 2016). The right career choice for students who enrolled in professional education is crucial as it has a tremendous influence on their future professional life and future accomplishment. Career choices are prominent among the most important factors that business students take into consideration since it will support them in their future reflection (Ahmed, Sharif, \& Ahmad, 2017). Nevertheless, Wong et al. (2019) reckoned that there are various research conducted on factors affecting career choice but there is no explicit evidence on which factors are most prominent over career choice in Malaysia. Thus, present study is conducted to study on factors affecting career choice of undergraduate students in Malaysia specifically at the Faculty of Business and Management, UiTM Puncak Alam.

\section{Personality}

Since there is no definite direction for choosing a career, Perger and Takacs (2016) suggested the students to understand their personal characteristics and associate them to their most compatible career. The way students evaluate themselves in association with a personality trait is a factor influencing the type of career to choose. Gwelo (2019) and Raveenther (2017) found that students' personalities influence their career choices. Kemboi, Kindiki, and Migio (2016) have stated that an individual's personality plays a significant role in their career choice in that they choose the career they prefer the most because it describes their unique identity, and it matches their personality the best. Gwelo (2019) further adds that students are more likely to choose a career that best suits their personality so that they can enjoy learning and gain satisfaction. Based on the review of past literature, the following hypothesis was developed:

Hypothesis 1: There is a relationship between personality and career choice.

\section{Parents or Guardians}

Parents play a vital role in every aspect of their children's lives including their career choice (Michele \& Francesco, 2018). Besides, Kumazhege (2017) also found there is a significant relationship between parents and career choices. Children (undergraduate students) tend to love their parents' ideal careers more than others if their careers provide a comfortable lifestyle, satisfaction, prestige, performance, and social status (Zhou, Guan, Xin, Mak \& Deng, 2016). According to Gwelo (2019), as children grow up, they gain a clear picture of their parents' careers. For instance, if one parent is a teacher, the child can also be driven to choose a career as a 
teacher. Notwithstanding, there is still a deficiency of research on how parental influences linked with undergraduates' career choice (Stritch \& Christensen, 2016). Thus, the following hypothesis was developed to study the relationship between parents or guardians and undergraduate students' career choice.

Hypothesis 2: There is a relationship between parents or guardians and career choice.

\section{Peer Groups}

During their study time, Daniel (2017) mentioned that university students always choose whom they want to friend with, their roommates, and classmates. They are more likely to choose peers who are systematically related to each other. Although peer selection is not explicitly voluntary, it may be related to peer characteristics. For instance, by enrolling in difficult or advanced courses, a good student will surround themselves with good peers. Empirical studies have proved to some degree, the peer influences an individual's career choice (Gwelo, 2019; Raheem et al., 2018). According to Raheem et al., (2018), children may fancy what their peer desire, to be with them, and as the peer influence grows, there will be an identical rise in students' career choice. Based on the review of past literature, the following hypothesis was developed:

Hypothesis 3: There is a relationship between peer groups and career choices.

\section{Career Guidance Counsellors}

Seldom students are uncertain about their strengths. They don't know what their career path or inclination might be. Career counsellors assist people in getting a clear picture of what's important to them, how they can prepare for their careers autonomously, and assist in making difficult decisions (Jain, 2017). According to Kok and Low (2017), students continually want expert career counsellors to supervise them to cultivate self-awareness in personal potentials, interests, knowledge, skills, weaknesses and explore career opportunities such as trends in employment, competencies needed to be in the fields, employment requirements, and job descriptions. This is in line with the findings of Eremie and Ibifari (2018) who found that there is a relationship between career counsellors and students' career choices. Thus, based on the previous findings, researchers try to seek the relationship between career guidance counsellors and career choices of students by establishing the following hypothesis:

Hypothesis 4: There is a relationship between career guidance counsellors and career choices.

\section{Environment}

Many perspectives distinguish the influence of environmental factors on student career choice. According to Raveenther (2017), environmental factors refer to complex physical factors which include a source of advice, social and economic issues, political issues that students may face in their daily lives. However, Kumazhege (2018) refers to different environmental factors. For example, home location, religion, nature of businesses and services, location of an educational institution, and socio-economic environment. Despite the differences, previous studies found out the significant influence of the environment on career choices (Eremie \& Ibifari; 2018, Kumazhege, 2017). Nevertheless, this study keen to seek the influence of similar environmental factors studied by Kumazhege (2017) and lead to the development of the following hypothesis: Hypothesis 5: There is a relationship between environment and career choices. 


\section{Opportunity}

Opportunity is an important determinant since a career path is a long-term process where students are assumed to get involved in a particular job by choosing the most favorable career that has a stable demand in the market (Gwelo, 2019). On top of that, Mncayi and Dunga (2016) stated that being exposed towards the available opportunities would make students have a good chance in choosing the finest career that suits their aptitudes. The opportunities may be in term of academic qualification, practical field attachment, and job shadowing. Nevertheless, the utmost possible opportunity would be employment opportunity. There is statistical data to prove that career choice is significantly impacted by opportunity (Gwelo, 2019). Gwelo (2019) highlighted that people always attempt to predict uncertain future. Similarly for students, they constantly striving to plan their careers for a stable future where excellent job opportunities are important factors that can influence career choices. Based on the statistical data, hypothesis 6 below were developed:

Hypothesis 6: There is a relationship between opportunity and career choice.

\section{Economic Considerations}

The economic situation denotes to the state in the local economy in which a person is going to search for their careers (Meddour, Abdo, Majid, Auf, \& Aman, 2016). It is true that economic growth in the country is connected to the increment in employment rates and the increment in people's spending capacity. A growing business will create more connections and more openings for employment. This will naturally draw students to those growing fields. This is because they may see great potential for their life growth and income. A study by Meddour et al. (2016) argued that demographic culture was different in exposing the influence of economic factor towards student's career choice. This is because abundant people crave to choose a career that could give them a sound basis for a better standard of living (Cavus, Geri, \& Turgunbayeva, 2015). Hence, the following hypothesis was developed to study the relationship between economic considerations and career choices:

Hypothesis 7: There is a relationship between economic considerations and career choices.

\section{Research Framework}

The framework in Figure 1 was developed by incorporating various factors that influence career choices that are supported by previous literature.

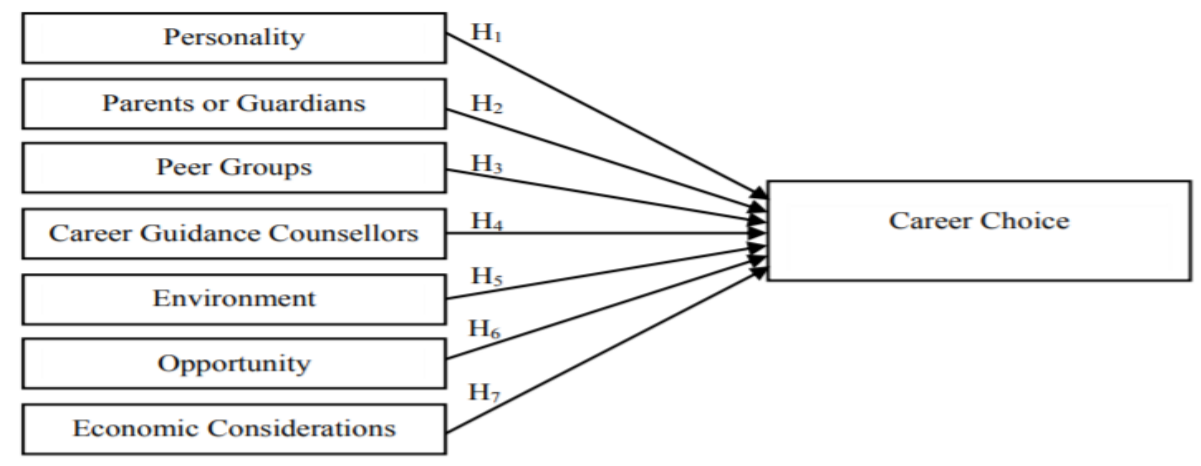

Figure 1. Research Framework of Factors Influencing Career Choice 


\section{Methodology}

The purpose of executing this study is to perform causal research that involves hypothesis testing. There were 436 final semester undergraduate students from the Faculty of Business and Management, UiTM Puncak Alam, and the sample frame was obtained. A census sampling by distributing the questionnaires to the whole population to ensure a good response rate because email questionnaires only result in a 30 percent response rate (Sekaran\& Bougie, 2016). The research instruments were adapted from previous studies. The instruments used for personality, parents or guardians, peer groups, career guidance counsellors, and the environment was adapted from Kumazhege (2017) namely Factors Influencing Technical College Students Vocational Choice Questionnaire (FITCSVCQ) while instruments for opportunity was adapted from Abbasi and Sarwat (2014), instruments for economic considerations was adapted from Cavus et al., (2015), and instruments for career choice was adapted from Özlen and Arnaut (2013). The research instruments were used to measure with a five-points of Likert-scales response. The questionnaires were distributed to the respondents using email since the final semester students are on their industrial training and are not available on campus.

\section{Result}

\section{Demographic Profile}

436 questionnaires were distributed to the last semester of undergraduate students in the Faculty of Business and Management, UiTM Puncak Alam and only 224 questionnaires were returned. The response rate is 51.37 percent and all that responses are usable for analysis. Table 1 depicts the detail analysis on respondents' demographic profile. 
INTERNATIONAL JOURNAL OF ACADEMIC RESEARCH IN PROGRESSIVE EDUCATION AND DEVELOPMENT

Vol. 10, No. 2, 2021, E-ISSN: 2226-6348 @ 2021 HRMARS

Table 1. Demographic Profile of 224 Respondents

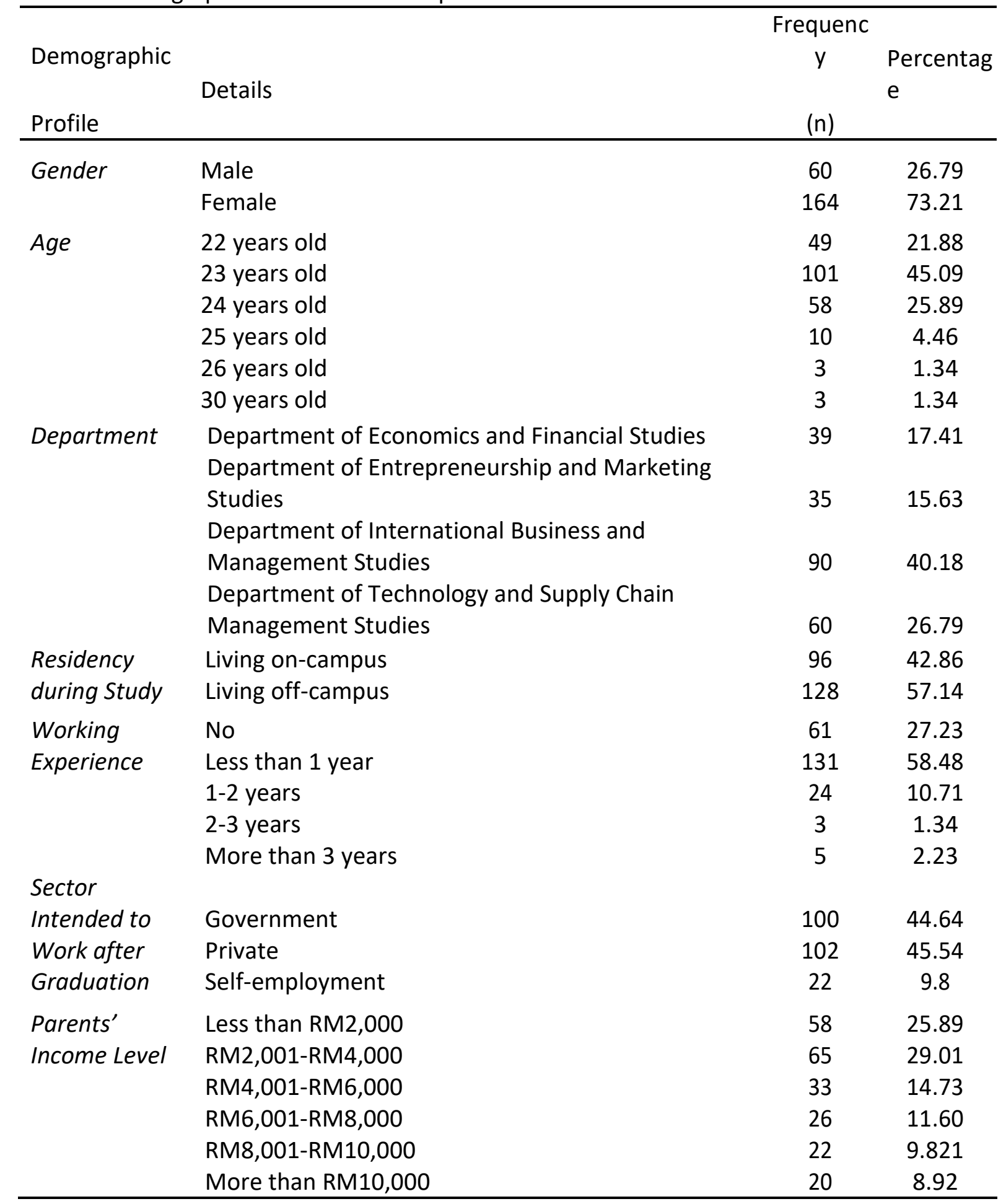

Table 2. Mean, reliability analysis, and Pearson correlation analysis 
Vol. 10, No. 2, 2021, E-ISSN: 2226-6348 @ 2021 HRMARS

\begin{tabular}{|c|c|c|c|c|c|c|c|c|c|c|}
\hline Variables & Mean & $\begin{array}{c}\text { Std. } \\
\text { Deviations }\end{array}$ & 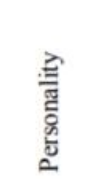 & 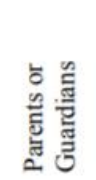 & 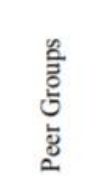 & 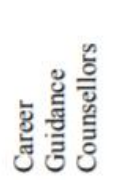 & 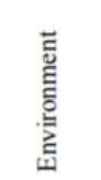 & $\begin{array}{l}\text { 产 } \\
\text { के } \\
\text { o. }\end{array}$ & 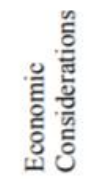 & 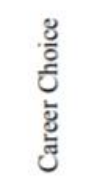 \\
\hline Personality & 4.13 & 0.53 & $(0.705)$ & & & & & & & \\
\hline Parents or Guardians & 3.27 & 0.87 & $0.180^{* *}$ & $(0.758)$ & & & & & & \\
\hline Peer Groups & 2.89 & 0.91 & $0.186^{* *}$ & $0.439^{* 2}$ & $(0.821)$ & & & & & \\
\hline Career Guidance Counsellors & 3.51 & 0.80 & $0.238^{* *}$ & $0.466^{\circ}$ & $0.433^{*}$ & $(0.712)$ & & & & \\
\hline Environment & 3.47 & 0.85 & $0.206^{* *}$ & $0.333^{* *}$ & $0.485^{* *}$ & $0.363^{* \prime}$ & (0.948) & & & \\
\hline Opportunity & 4.08 & 0.70 & $0.257^{* *}$ & $0.187^{* *}$ & 0.109 & $0.228^{* *}$ & $0.272^{*}$ & $(0.704)$ & & \\
\hline Economic Considerations & 4.35 & 0.56 & $0.301^{* *}$ & 0.068 & $0.161^{\circ}$ & 0.080 & $0.295^{* *}$ & $0.527^{* *}$ & $(0.720)$ & \\
\hline Career Choice & 3.80 & 0.65 & $0.469^{\circ}$ & $0.238^{* *}$ & 0.065 & $0.283^{* *}$ & $0.271^{* *}$ & $0.210^{* *}$ & $0.229^{\circ *}$ & $(0.956)$ \\
\hline
\end{tabular}

Note. Coefficient's alpha are in parentheses. **. Correlation is significant at the 0.01 level (2tailed) *. Correlation is significant at the 0.05 level (2-tailed). Cronbach's alpha values are put in a bold bracket.

\section{Mean, Reliability Analysis, and Pearson Correlation Analysis}

Based on Table 2, the mean for personality, opportunity, economic considerations, and career choice are 4.13, 4.08, 4.35, and 3.80, respectively. Based on Landell (1997), these values can be considered as high. Other than that, the mean for parents or guardians, peer groups, career guidance counsellors, and environment are 3.27, 2.89, 3.51, and 3.47, respectively. Alluding to Landell (1997), these values can be considered as medium. The result for internal consistency in this study were considered as reliable to be asked to the respondents.

\section{Multiple Regression Analysis}

Table 3. Regression analysis

\begin{tabular}{|c|c|c|c|c|c|}
\hline$R$ square & & .31 & & & \\
\hline F-stat & & 3.90 & & & \\
\hline Sig. & & .00 & & & \\
\hline & Unsta & lardized & & & \\
\hline Model & Beta & & Standardized & $\mathrm{t}$ & Sig. \\
\hline & B & Std. Error & & & \\
\hline (Constant) & 0.70 & 0.37 & & 1.88 & 0.06 \\
\hline Personality & 0.48 & 0.08 & 0.39 & 6.43 & 0.00 \\
\hline Parent or Guardians & 0.10 & 0.05 & 0.14 & 1.99 & 0.05 \\
\hline Peer Groups & -0.17 & 0.05 & -0.24 & -3.35 & 0.00 \\
\hline Career Guidance & & & & & \\
\hline Counsellors & 0.13 & 0.06 & 0.16 & 2.35 & 0.02 \\
\hline Environment & 0.14 & 0.05 & 0.18 & 2.67 & 0.01 \\
\hline Opportunity & -0.03 & 0.07 & -0.03 & -0.48 & 0.63 \\
\hline Economic & & & & & \\
\hline Considerations & 0.10 & 0.08 & 0.09 & 1.28 & 0.20 \\
\hline
\end{tabular}

Note. Dependent Variable: Career Choice 
The R square of 0.31 in Table 3 implies that all the independent variables (personality, parents or guardians, peer groups, career guidance counsellors, environment, opportunity, and economic consideration) in this study explained 31 percent of the variance in the dependent variable (career choices). 68.90 percent of the variance in the career choice may be indicated by other independent variables that are not included in this study. The F-test is significant ( $F$ stat=13.90, $p$-value $=0.00$ ) based on the $p$-value (given by F-Sig.) below than 0.05 . Thus, the linear model is overall valid to explain the relationship between the independent variables and the dependent variable. The independent variables of personality, parents or guardians, peer groups, career guidance counsellors, and environment show a $p$-value below the 5 percent significant level which is 0.00 . As a result, these variables are significant and $\mathrm{H} 1, \mathrm{H} 2, \mathrm{H} 3, \mathrm{H} 4$ and $\mathrm{H} 5$ are supported. On the other hand, the opportunity variable is not significant. This is because the $p$-value for the opportunity variable is 0.63 , which is above the 5 percent of significant level. Hence, the opportunity is not significantly related to students' career choices and $\mathrm{H} 6$ is not supported. Similarly, for the economic considerations' variable, its $p$-value is 0.20 , which is also more than 5 percent of a significant level. Therefore, the economic considerations also not significantly related to students' career choices and $\mathrm{H} 7$ is not supported.

\section{Conclusion}

In summary this study has achieved its objectives in identifying the significant factors contributing the career choice among graduating students of a business faculty at a public university in Malaysia. Based on the result of standardized beta coefficient of multiple regression analysis, the most significant factor was personality. Then followed by the following factors according to ranks, i.e., peer groups, environment, career guidance counsellors, and parent or guardians. Whilst economic considerations and opportunity were not significant factors. Therefore, only five out of seven factors were the significant predictors that influence the graduating students' career choices that should be well concerned by the university, policy makers as well human resource practitioners. The result of personality as one of the biggest antecedents of career choice had concurred with the finding of Gwelo (2019); Raveenther (2017). Thus, it is suggested that the student should familiarize themselves with their personality type by taking a career personality test based on standardized psychological inventories with the help of experts and identify their career interests so that they make the right career choices.

Other than that, this study found that there is a negative relationship between peer groups and students career choices. This indicates that peers with a different major at the Faculty of Business and Management at UiTM Puncak Alam would provide different career choice viewpoints. In addition, this study also reveals the significant relationship between environment and career choices, and this is supported by previous studies (Eremie \& Ibifari; 2018, Kumazhege, 2017; Raveenther, 2017). This means that the shorter the traveling distance from home to work, the greater the possibility of a student to choose that career. The study also indicated that career guidance counsellors is an influential factor that is deliberated by students in making career choices. This result is concurred by the previous studies (Eremie \& Ibifari, 2018; Jain, 2017). Besides, it was also found that parents or guardians have a significant role in influencing the students' career choices. This result was in line with the finding of Kumazhege (2017). It is recommended that parents or guardians should be encouraged to cultivate further interest in 
Vol. 10, No. 2, 2021, E-ISSN: $2226-6348$ @ 2021 HRMARS

their children's career plans since the children could be more engaged in the career decision when parents or guardians provide them with encouragement, information, and resources when required.

Surprisingly, this study found out that opportunity was not one of the influential factors in making a career choice. This result was in line with the finding of Ahmed et al., (2017). Similarly for economic considerations. The study also found no relationship between economic considerations and career choice. This result is concurred by Ramanchandram, Abdullah, and Asma (2015) who highlighted that issues related to income or the economic factors do not certainly the factor students emphasized in choosing a career. Thus, future research may shift their focus on other factors that may also influence students' career choices. This is because, through multiple regression analysis, it was found that all the variables studied accounted for only 31.1 percent of the variance in career choice. Besides, future researchers can conduct similar studies on a larger population or sample. As can be seen, this study was conducted among final semester students from the Faculty of Business and Management, UiTM Puncak Alam, Malaysia. Hence, future studies may extend the scope of this study to other universities as well.

\section{Acknowledgement}

This research is funded by the Faculty Internal Fund (600-IRMI 5/3/DDF (FPP) (023/2019)) by Faculty of Business and Management, Universiti Teknologi MARA, Bandar Puncak Alam, Selangor, Malaysia.

\section{References}

Abbasi, M. N., \& Sarwat, N. (2014). Factors inducing career choice: Comparative study of five leading professions in Pakistan. Pakistan Journal of Commerce and Social Sciences, 8(3), 830-845.

Ahmed, K. A., Sharif, N., \& Ahmad, N. (2017). Factors influencing students' career choice: Empirical evidence from business students. Journal of Southeast Asian Research, 3. doi:10.5171/2017.718849

Ates, S. S. (2016). The affecting factors of career start in institutions of higher education: Application with Turkish Aviation Students. Journal of Social Sciences, 2(4), 27-34.

Bubic', A., \& Ivaniševic, K. (2016). The role of emotional stability and competence in young adolescents' career judgments. Journal of Career Development, 43(6), 498-511. doi: 10.1177/0894845316633779

Cavus, S., Geri, S., \& Turgunbayeva, K. (2015). Factors affecting the career plans of university students after graduation. International Journal of Humanities and Social Science, 5(5).

Daniel, R. (2017). Relationship among self-esteem, peer group influence and academic performance of senior secondary school students in Gusau local government area of Zamfara state. Unpublished M.Ed Dissertation submitted to department of educational foundations, UDUS Nigeria.

Eremie, M. D., \& Ibifari, B. (2018). Factors influencing students' career choice in secondary schools in Rivers State: Implication for career counselling. International Journal of Innovative Education Research, 6(4), 93-100. 
Gwelo, A. S. (2019). Determinants of career choice among university students. Malaysian Online Journal of Educational Management, 7(1), 1-19.

Jain, P. (2017). Impact of career guidance and counselling on student's career development. International Journal of Research-Granthaalayah, 5(6), 49-52. doi:https://doi.org/10.5281/zenodo.805895

Kemboi, R., Kindiki, N., \& Misigo, B. (2016). Relationship between personality types and career choices of undergraduate students: A case of Moi University, Kenya. Journal of Education and Practice., 7(3), 102-112.

Koech, J., Bitok, J., Rutto, D., Koech, S., Okoth, J. O., Korir, B., \& Ngala, H. (2016). Factors influencing career choices among undergraduate students in public universities in Kenya: A case study of University of Eldoret. International Journal of Contemporary Applied Sciences, $3(2), 50-63$.

Kok, J. K., \& Low, S. K. (2017). Proposing a collaborative approach for school counselling. International Journal of School \& Educational Psychology, 5(4), 1-9. doi:https://doi.org/10.1080/21683603.2016.1234986

Kumazhege, S. Z. (2017). Factors that influence vocational choice among Technical College students in North East of Nigeria. International Journal of Education and Evaluation, 3(6), 28-39.

Landell, K. (1997). Management by Menu. London: Wiley And Sons Inc.

Leo, M. (2019). What You Didn't Know About Fresh Graduate Unemployment in Malaysia [Infographic]. Retrieved from EduAdvisor: https://eduadvisor.my/articles/what-didntknow-fresh-graduate-unemployment-malaysia-infographic/

Meddour, H., Abdo, A. A., Majid, A. H., Auf, M. A., \& Aman, A. M. (2016). Factors affecting career choice among undergraduate students in Universitas Indonesia. International Journal of Economic Perspectives, 10(4), 630-644.

Michele, R., \& Francesco, V. (2018). From the Cradle to The Grave: The Influence of Family Background on The Career Path of Italian Men. Oxford Bulletin of Economics, 80(6), 1-27.

Mncayi, P., \& Dunga, S. H. (2016). Career choice and unemployment length: A study of graduates from a South African university. Industry and Higher Education, 30(6), 413-423.

Mtemeri, J. (2017). Factors influence the choice of career pathways among high school students in Midlands Province, Zimbabwe. Degree of Doctor of Education, University of South Africa, 1-6.

Ng, E. S., Gossett, W. C., Chinyoka, S., \& Obassi, I. (2016). Public vs Private sector employment: An exploratory study of career choice among graduate management student in Botswana. Personnel Review, 45(6), 1367-1385. doi:https://doi.org/10.1108/PR 1020140241

Özlen, M. K., \& Arnaut, D. (2013). Career decisions of university students. Journal of Community Positive Practices, XIII(2), 92-107.

Perger, M., \& Tackács, I. (2016). Factors contributing to students' academic success based on the students' opinion at BME Faculty of Economic and Social Sciences. Periodica Polytechnicawong Social and Management Sciences, 24(2), 119-135.

Raheem, A. I., Abdulkadir, A. O., \& Zakkariyah, A.-H. A. (2018). Peer group influence and occupational choice of students in some selected senior secondary schools in Sokoto Metropolis, Sokoto State, Nigeria. Journal of Education and Practice, 9(35), 9-14. 
Ramanchandram, R., Abdullah, S., \& Asma, A. (2015). Factors affecting career choice of undergraduate students in Universiti Utara Malaysia. Conference on Business Management Research II, 215-223.

Raveenther, A. (2017). The relationship between career choice and environment, opportunity and personality. International Journal of Scientific \& Engineering Research, 8(3), 63-67.

Sekaran, U., \& Bougie, R. (2016). Research Methods for Business: A Skill-Building Approach. Haddington: John Wiley \& Sons.

Stritch, J. M., \& Christensen, R. K. (2016). Raising the next generation of public servants? Parental influence on volunteering behavior and public service career aspirations. International Journal of Manpower, 37(5), 840-858.

University Transformation Division. (2019). UiTM Facts and Figures. Retrieved from Universiti Teknologi Mara (UiTM): https://www.uitm.edu.my/index.php/en/9-about-uitm/363-uitmfacts-and-figures

Wong, S. C., Lim, J. Y., Lim, C. S., \& Hong, K. T. (2019). Empirical study on career choices among undergraduates: A PLS-SEM Hierarchical Component Model (HCM) Approach. International Journal of Human Resource Studies, 9(2).

Zhou, W., Guan, Y., Xin, L., Mak, M. K., \& Deng, Y. (2016). Career success criteria and locus of control as indicators of adaptive readiness in the career adaptation model. Journal of Vocational Behavior, 94, 124-130. 